\title{
Novel RP-HPLC-DAD and RP-UPLC Methods for Simultaneous Determination of Cefaclor and Methylparaben in their Dosage form and in its Impurity Cefaclor -Delta-3- Isomer
}

\author{
Mohamed EM Hassouna ${ }^{1 *}$ and Mahmoud A Mohamed ${ }^{2}$ \\ ${ }^{1}$ Department of Chemistry, Faculty of Science, Beni-Suef University, Egypt \\ ${ }^{2}$ HIKMA group, Pharmaceutical Company, Beni-Suef, Egypt
}

Submission: February 06, 2019; Published: February 21, 2019

*Corresponding author: Mohamed EM Hassouna, Department of Chemistry, Faculty of Science, Beni-Suef University, Egypt

\begin{abstract}
Cefaclor (CFC), a new orally administered for the second generation of cephalosporin is the most effective for treatment of acute otitis media in children. So, the main task of this work is to develop and validate a novel RP-HPLC and RP-UPLC methods for simultaneous determination of cefaclor and methylparaben (MP) in their powder for oral suspension (POS) dosage form and in its impurity cefaclor-delta-3- isomer ( $\left.\mathrm{CD}_{3} \mathrm{I}\right)$. The chromatographic system is performed at ambient temperature using mobile phase composing of acetonitrile: methanol: $0.02 \mathrm{M}$ ammonium dihydrogen phosphate pH $4.7 \pm 0.1$ (25:10:65, v/v) on Agilent Eclipse XDB C18 column (250 mm X $4.6 \mathrm{~mm}, 5 \mu \mathrm{m}$ particle size) at flow rate 1.0 $\mathrm{mL} / \mathrm{min}$, injection volume $20 \mu \mathrm{L}$ for RP-HPLC and Waters CORTECS® C18 column (50 mm $\times 4.6 \mathrm{~mm}, 2.7 \mu \mathrm{m}$ particle size) at flow rate $0.3 \mathrm{~mL} /$ min, injection volume $0.2 \mu \mathrm{L}$ for RP-UPLC and UV detection at $265 \mathrm{~nm}$. The method is linear for all analytes in the concentration range (70-700) $\mu \mathrm{g} / \mathrm{mL}$ for CFC and $(10-200) \mu \mathrm{g} / \mathrm{mL}$ for MP with correlation coefficients $>0.999$. The suggested method is validated according to ICH guidelines. Hence it is suitable for laboratory control of raw materials, bulk and finished products.
\end{abstract}

Keywords: Cefaclor; Methylparaben; Cefaclor -Delta-3- Isomer; RP- UPLC; RP- HPLC

\section{Introduction}

Cefaclor (CFC) therapy is very effective for treating children aged 2-6 years affected by acute otitis media, with no significant difference related to treatment duration. Short-course treatments appear better in terms of compliance and tolerability [1]. Both cefaclor and amoxy-clav caused a significant improvement in all the signs and symptoms in the treatment of acute otitis media after 10-days treatment period. However, between-the-group comparisons showed that the lowering in most of the symptoms was significantly more in cefaclor drug than amoxicillin-clav [2]. CFC, (Figure 1a) is a semisynthetic product derived from a fermentation product follows the second generation of cephalosporin antibacterial group for oral administration. It is chemically named as (6R,7R)-7-[[(2R)-2-Amino-2-phenylacetyl] amino]-3-chloro-8-oxo-5-thia-1-azabicyclo [4.2.0] oct-2-ene2-carboxylic acid monohydrate. It has a molecular formula of $\mathrm{C}_{15} \mathrm{H}_{14} \mathrm{ClN}_{3} \mathrm{O}_{4} \mathrm{~S}, \mathrm{H}_{2} \mathrm{O}$ and a molecular weight of 385.8. It has characters of appearance; White or slightly yellow powder and has solubility as slightly soluble in water, practically insoluble in methanol and in methylene chloride [3]. CFC is indicated for the treatment of the following types of infections caused by or likely to be caused by susceptible organisms: lower respiratory infections, including pneumonia, bronchitis, and exacerbations of chronic bronchitis. Also, upper respiratory infections, including pharyngitis, tonsillitis and otitis media. Skin and skin structure infections. Urinary tract infections, including pyelonephritis and cystitis.

In more serious infections, otitis media, and infections caused by less susceptible organisms, the recommended dosage is $40 \mathrm{mg} / \mathrm{kg} /$ day in divided doses every 8 to 12 hours (maximum $2 \mathrm{~g} /$ day). For otitis media, 12 hourly administration appears equally effective [4]. MP (Figure 1b), is used as antimicrobial preservative. It was chemically named as (methyl 4-hydroxybenzoate), a molecular formula of $\left(\mathrm{C}_{8} \mathrm{H}_{8} \mathrm{O}_{3}\right)$ and a molecular weight of 152.1. It has characters of appearance white or almost white, crystalline powder or colorless crystals and has characteristic of solubility as very slightly soluble in water, freely soluble in ethanol (96 per cent) and in methanol [3]. Cefaclor -delta-3- isomer (CD3I), (Figure 1a) is used as antibacterial broad-spectrum drug. It was chemically named as (2R,6R,7R)- and (2S,6R,7R)-7-[[(2R)-2-amino-2-phenylacetyl] amino]-3-chloro-8- oxo-5-thia- 1-azabicyclo [4.2.0] oct-3-ene-2carboxylic acid (delta-3-cefaclor). It has a molecular formula of 
$\mathrm{C}_{15} \mathrm{H}_{14} \mathrm{ClN}_{3} \mathrm{O}_{4} \mathrm{~S}$, and a molecular weight of 367.8 . It has characters of appearance: white powder and has solubility as slightly soluble in water [3].

HPLC method for determination of CFC is officially reported in both of British Pharmacopeia (BP) and United States Pharmacopeia (USP) [5]. It is still a limited number of analytical methods that are reported for the determination of CFC and MP individually or in combination with other drugs including high performance liquid chromatography (HPLC) [6-16], capillary electrophoresis and electrochemical methods [17-19], thin layer chromatography (TLC) [20-22], UPLC and mass spectrometry [23], kinetics degradation and spectrophotometric [24-31], and comparative in vitro dissolution studies [32-34]. For the best of our knowledge, there is no RP-HPLC and RP-UPLC methods for simultaneous determination of cefaclor and methylparaben in their dosage form and in its impurity (cefaclor -delta-3-isomer). So, it is thought worthwhile to develop and validate a simple, precise and accurate RP-HPLC and RP-UPLC methods to resolve this binary mixture and determine cefaclor -delta-3-isomer in their dosage form.<smiles>N[C@@H](C(=O)N[C@@H]1C(=O)N2C(C(=O)O)=C(Cl)CS[C@H]12)c1ccccc1</smiles>

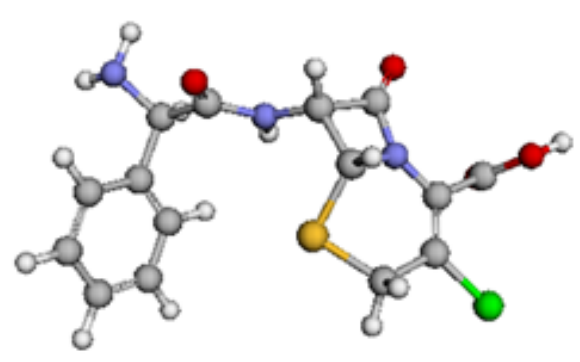

Figure 1a: Chemical structures of (a) Cefaclor\& cefaclor delta-3- isomer.

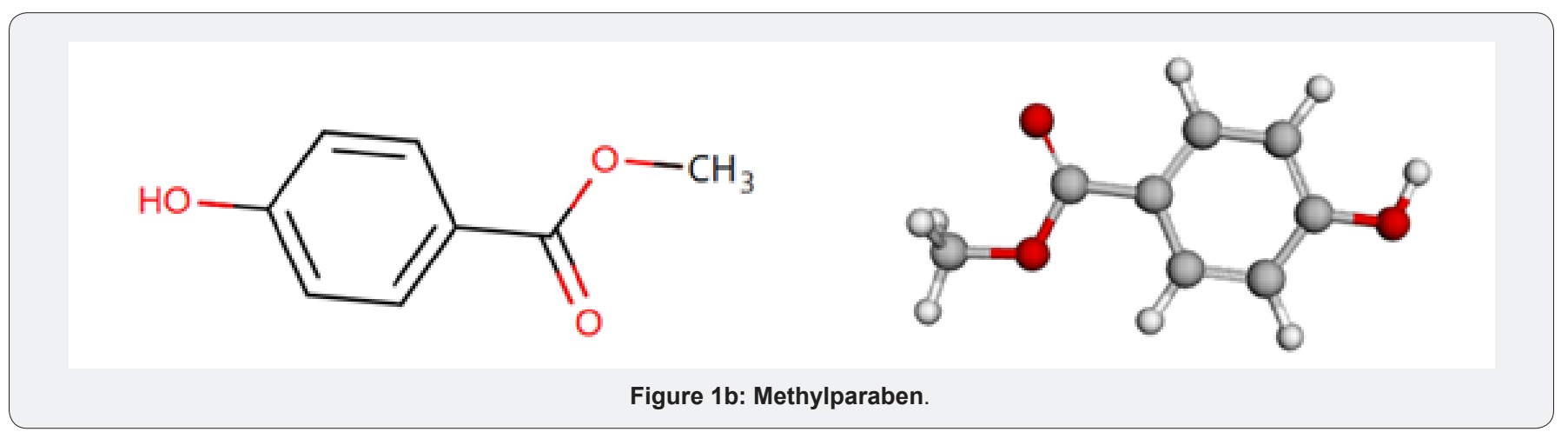

Experimental

\section{Materials and Reagent}

CFC and MP are kindly supplied by Hikma pharmaceutical industries company, Beni-Suef, Egypt with potency $>99.0 \%$. Cefaclor-delta-3-isomer is purchased from store of USP with lot no. (R044L0). Alfatil ${ }^{\circledR} 125 \mathrm{mg} / 5 \mathrm{~mL}$ "POS" (Batch No. 0004D4) is manufactured by Laboratories Ethypharm, France.

\section{Apparatus}

Agilent 1260 infinity (Germany) HPLC system is supplied with preparative auto sampler (G1329B), Quaternary pump (G1311C), Thermostatic column compartment (G1316A), DAD detector VL (G1315D) and ChemStation (chem32) Software. Waters $\AA$ UPLC System, a quaternary liquid chromatography provides plug with $2489 \mathrm{UV} / \mathrm{Vis}$ Detector (A17VTU408A), Sample manager FTN-R (D17VSM260N), Quaternary solvent manager-R (C17VQS618G) and Empower ${ }^{\mathrm{TM}} 3$ Software. UV- 1800 double beam UV-Visible spectrophotometer (Shimadzu-Japan) with the highest resolution and spectral bandwidth of $(1 \mathrm{~nm}$ from 190-1100 nm range) is used for all absorbance measurements.
It is matched with $1 \mathrm{~cm}$ quartz cells. Perform data analysis by software (UV-Probe 2.3.3). METTLER TOLEDO density meter.

\section{Solvent Preparation}

Use the mobile phase as solvent.

\section{Standard Solutions for Assay}

Stock standard solution (1000 $\boldsymbol{\mu g} / \mathrm{mL}$ of CFC): Carefully transfer $100 \mathrm{mg}$ of CFC into $100 \mathrm{~mL}$ volumetric flask, add about $70 \mathrm{~mL}$ of the solvent. Sonicate for $10 \mathrm{~min}$ till complete dissolution then completes to mark with the same solvent and mix well.

Stock standard solution (1000 $\boldsymbol{\mu g} / \mathbf{m L}$ of MP): Similarly weigh $100 \mathrm{mg}$ of MP into $100 \mathrm{~mL}$ volumetric flask, add about 70 $\mathrm{mL}$ of the solvent Sonicate for $10 \mathrm{~min}$ till complete dissolution then completes to mark with the same solvent and mix well.

Standard solution $(625 \mu \mathrm{g} / \mathrm{mL})$ of CFC and $(150 \mu \mathrm{g} / \mathrm{mL})$ of MP: Accurately transfer $12.5 \mathrm{~mL}$ aliquot from CFC and $3 \mathrm{~mL}$ of MP the previously prepared stock standard solutions into $20-\mathrm{mL}$ volumetric flasks. Complete to mark with the same solvent. Mix 
well and filter through $0.45 \mu \mathrm{m}$ PTFE membrane filter and inject into the chromatographic system (Figure 2).

\section{Specific Gravity Determination}

Take one bottle, add the quantity of water as mentioned in the product label. Close the bottle and shake well for 10 minutes.
Use suitable calibrated analytical balance, weigh an empty clean and dry pycnometer. Fill the pycnometer completely with water and weigh. Then repeat filling it with the reconstituted suspension and weigh and determine the specific gravity (density) according to the following equation:

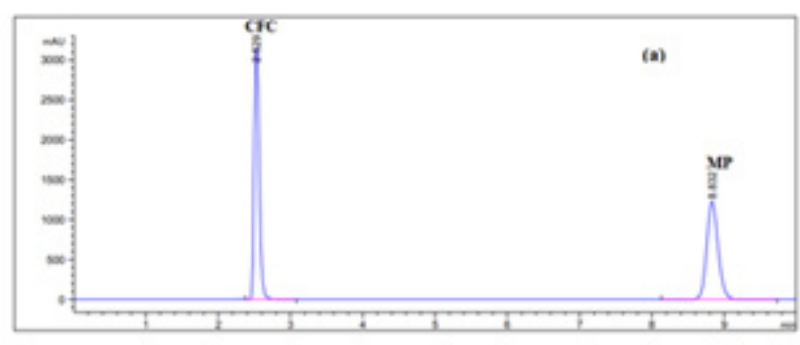

(a)

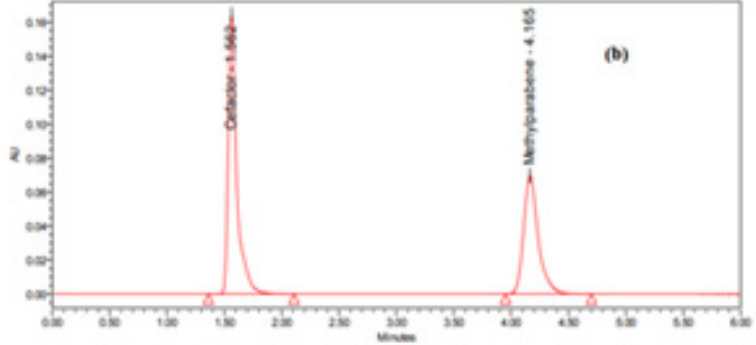

(b)

Figure 2: Standard solution of $625 \mu \mathrm{g} / \mathrm{mL}$ of CFC and $150 \mu \mathrm{g} / \mathrm{mL}$ MP (a) HPLC chromatograms and (b) UPLC chromatograms using solvent as blank.

Specific Gravity (Density) $=\mathrm{Wt}_{\mathrm{s}}-\mathrm{Wt}_{0} / \mathrm{WtW}-\mathrm{Wt}_{0}$

Where;

$\mathrm{Wt}_{0}$ : Weight of empty pycnometer.

Wts: Weight of pycnometer filled with sample.

Wtw: Weight of pycnometer filled with water.

Or use the automated METTLER TOLEDO density meter.

\section{Pharmaceutical Preparation (Alfatil ®125 mg /5 mL)}

Constitute bottle of Alfatil $₫ 125 \mathrm{mg} / 5 \mathrm{~mL}$ POS as directed in the label and shake well for 10 minutes using multi shaker.

\section{Related Compounds}

Use the previously determined specific gravity to calculate the required weight per grams for each test as the following equation:

Required weight for each test $=$ Specific gravity $x$ volume $(5 \mathrm{~mL})$

Transfer an accurately weighed portion of the resulting suspension, freshly mixed and free from air bubbles, dilute quantitatively with solvent in $200-\mathrm{mL}$ volumetric flask to obtain a final solution (equivalent to about $125 \mathrm{mg}$ of CFC and $30 \mathrm{mg}$ MP). Sonicate if necessary, to ensure complete dissolution of the CFC. Filter through $0.45 \mu \mathrm{m}$ PTFE membrane filter and inject into the chromatographic system.

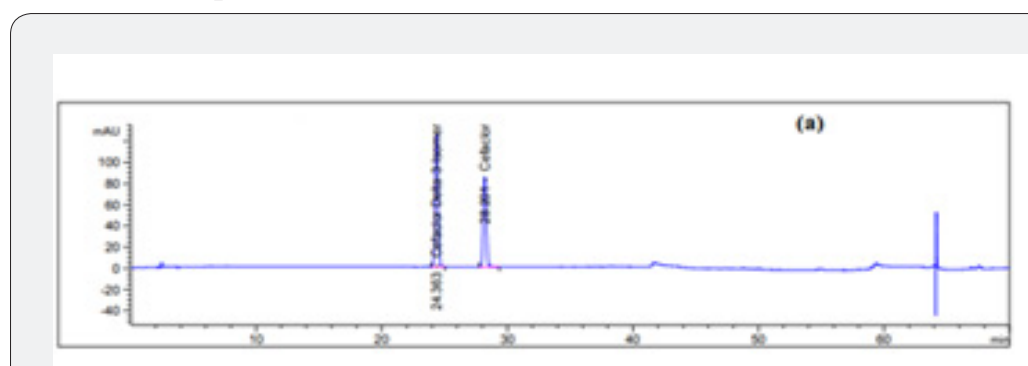

(a)

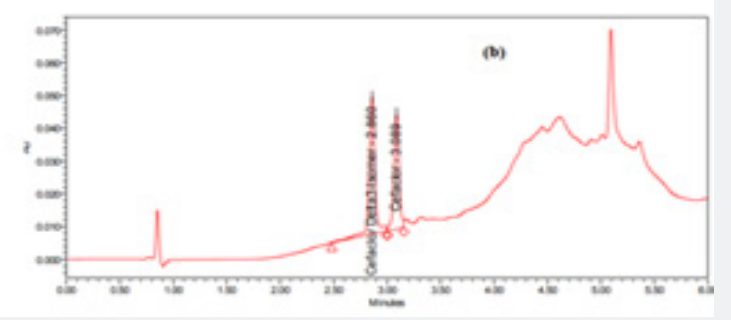

(b)

Figure 3: Standard solution of $50 \mu \mathrm{g} / \mathrm{mL}$ of each of CFC and CD3I (a) HPLC chromatograms and (b) UPLC.

System suitability solution: dissolve a quantity of USP cefaclor, delta-3 isomer RS in the standard solution to obtain a solution having a concentration of about $0.05 \mathrm{mg}$ per $\mathrm{mL}$ and filter through $0.45 \mu \mathrm{m}$ PTFE membrane filter and inject into the chromatographic system (Figure 3 ). Chromatograms using solvent as blank. Test solutions: constitute a bottle of Alfatil ®125 mg / $5 \mathrm{~mL}$ POS as directed in the label and shake well for 10 minutes using multi shaker. Transfer an accurately weighed portion of sample, freshly mixed and free from air bubbles, equivalent to about $50 \mathrm{mg}$ of cefaclor (about $1.9066 \mathrm{gm}$ ), to 10 -mL volumetric flasks, dilute each with solvent to volume, and mix. Sonicate briefly if necessary, avoid heating and filter through $0.45 \mu \mathrm{m}$ PTFE membrane filter and inject into the chromatographic system (Figure 4).

\section{Mobile Phase Preparation}

a) Solution A: Dissolve $2.3 \mathrm{~g}$ of ammonium dihydrogen phosphate in $1000 \mathrm{~mL}$ of water and adjust with phosphoric acid to a $\mathrm{pH}$ of $4.7 \pm 0.1$. 


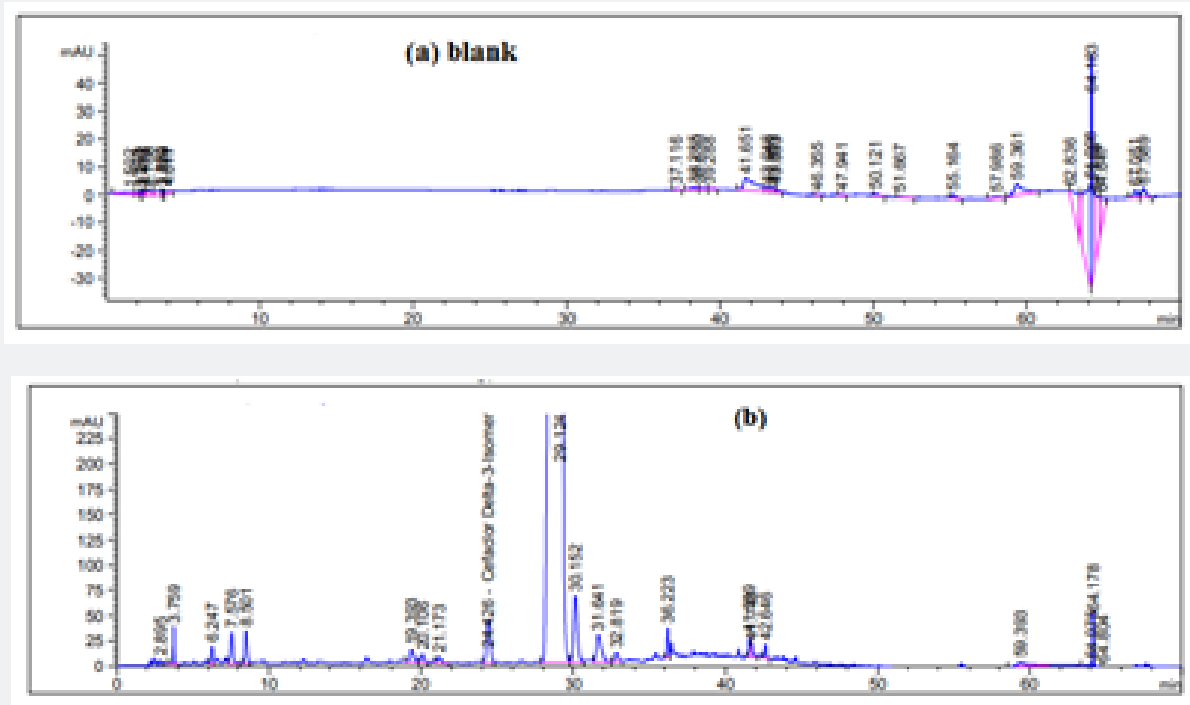

Figure 4: HPLC chromatograms of (a) blank (b) Related compound of Alfatil 125 mg POS chromatograms using solvent as blank.

Table 1: The HPLC chromatograph for related compound is programmed as follows.

\begin{tabular}{|c|c|c|c|c|c|}
\hline \multirow{2}{*}{ Initial } & \multirow{2}{*}{ Flow } & \multirow{2}{*}{ Inj. Vol } & Solution A & Solution B & \multirow{2}{*}{ Elution } \\
\cline { 3 - 5 } & & & (\%) & 10 & equilibration \\
\hline 0 & 1 & $20 \mu \mathrm{L}$ & 90 & 30 & linear gradient \\
\hline 28 & 1 & $20 \mu \mathrm{L}$ & 70 & 30 & linear gradient \\
\hline 42 & 1 & $20 \mu \mathrm{L}$ & 70 & 100 & isocratic \\
\hline 55 & 1 & $20 \mu \mathrm{L}$ & 0 & 10 & reset composition \\
\hline 60 & 1 & $20 \mu \mathrm{L}$ & 90 & 90 & re-equilibration \\
\hline 70 & 1 & $20 \mu \mathrm{L}$ & 90 & & \\
\hline
\end{tabular}

Table 2: The UPLC chromatograph for related compound is programmed as follows.

\begin{tabular}{|c|c|c|c|c|c|}
\hline \multirow{2}{*}{ Initial } & \multirow{2}{*}{ Flow } & \multirow{2}{*}{ Inj.Vol } & Solution A & Solution B & \multirow{2}{*}{ Elution } \\
\cline { 3 - 5 } & & & (\%) & 10 & equilibration \\
\hline 0 & 0.3 & $0.2 \mu \mathrm{L}$ & 90 & 30 & linear gradient \\
\hline 1.8 & 0.3 & $0.2 \mu \mathrm{L}$ & 70 & 30 & linear gradient \\
\hline 2.7 & 0.3 & $0.2 \mu \mathrm{L}$ & 70 & 100 & isocratic \\
\hline 3.6 & 0.3 & $0.2 \mu \mathrm{L}$ & 0 & 10 & reset composition \\
\hline 4.4 & 0.3 & $0.2 \mu \mathrm{L}$ & 90 & 90 & re-equilibration \\
\hline 6 & 0.3 & $0.2 \mu \mathrm{L}$ & 90 & & 10 \\
\hline
\end{tabular}

b) Solution B: Prepare a mixture of methanol and acetonitrile (30:70), degassing for not more than 2 minutes (Tables 1 \& 2).

\section{Construction of Calibration curves}

Separately transfer different aliquots from the stock standard solutions into separate series of $10 \mathrm{~mL}$ volumetric flasks covering the concentration ranges (70-700) $\mu \mathrm{g} / \mathrm{mL}$ for CFC and (10-200) $\mu \mathrm{g} / \mathrm{mL}$ for MP. Triplicate $20 \mu \mathrm{L}$ injections are injected for each concentration applying the recommended chromatographic conditions. The chromatograms are recorded, and the peak areas of CFC and MP are estimated, the calibration curves relating the obtained integrated peak areas to the corresponding concentrations are constructed and the regression equations are computed.

\section{Results and Discussion}

\section{Methods Development and Optimization}

Many systems of different compositions and ratios are tried including organic: methanol (100\%); methanol: purified water (50:50, v/v) and acetonitrile: purified water (50:50, v/v). Also ( 0.2 to $2.0 \mathrm{~mL} / \mathrm{min}$ ) flow rates are tried on HPLC and UPLC system, to gain the optimum wavelength for the solution, 20 $\mu \mathrm{g} / \mathrm{mL}$ of $\mathrm{CFC}$ and $25 \mu \mathrm{g} / \mathrm{mL}$ of MP are measured at 200 to 400 $\mathrm{nm}$ (Figure 5). Thus, $265 \mathrm{~nm}$ was selected as the most suitable wavelength. Preliminary studies involved trying C18 reversed 
phase columns. The best developing system using mobile phase composing of acetonitrile: methanol: 0.02M ammonium dihydrogen phosphate $\mathrm{pH} 4.7 \pm 0.1(25: 10: 65, \mathrm{v} / \mathrm{v})$ on Agilent Eclipse XDB C18 column ( $250 \mathrm{~mm}$ X $4.6 \mathrm{~mm}, 5 \mu \mathrm{m}$ particle size) at flow rate $1.0 \mathrm{~mL} / \mathrm{min}$, injection volume $20 \mu \mathrm{L}$ for RP-HPLC and Waters CORTECS $\AA$ C18 column $(50 \mathrm{~mm} \times 4.6 \mathrm{~mm}, 2.7 \mu \mathrm{m}$ particle size) at flow rate $0.3 \mathrm{~mL} / \mathrm{min}$, injection volume $0.2 \mu \mathrm{L}$ for RP-UPLC and UV detection at $265 \mathrm{~nm}$. Another advantage for UPLC system is the relatively short run time (6min) of the analysis, under isocratic conditions. This selected developing system allows good separation with good $R_{t}$ values without tailing of the separated bands and good theoretical plates.

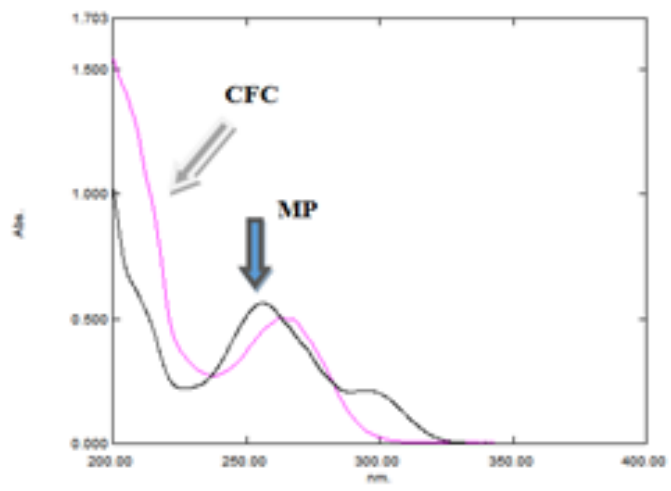

Figure 5: Zero order absorption spectra of $20 \mu \mathrm{g} / \mathrm{mL}$ of $\mathrm{CFC}$ and $25 \mu \mathrm{g} / \mathrm{mL}$ of MP using solvent as blank.

\section{Method Validation}

The proposed method is validated, in accordance with ICH guidelines [35].

\section{Linearity and Range}

The linearity of the suggested methods is obtained in the concentration range $(70-700 \mu \mathrm{g} / \mathrm{mL})$ for $\mathrm{CFC}$ and $(10-200 \mu \mathrm{g} /$ $\mathrm{mL}$ ) for MP. From the graphical presentation, the relation of peak response (A) plotted at X axis and concentration (C) plotted at $Y$ axis is evaluated on the base of least-square linear regression equation $(A=$ slope $C+Y$ intercept). The LOD and LOQ of the method are calculated using the expression (3.3\%/ slope) and $(10 \sigma /$ slope $)$ respectively. The obtained coefficient of regression is $>0.999$. Linearity results are shown in (Table 3).

Table 3: Regression and validation parameters of the proposed HPLC and UPLC methods for determination of CFC and MP.

\begin{tabular}{|c|c|c|c|c|}
\hline Parameter & \multicolumn{2}{|c|}{ HPLC } & \multicolumn{2}{c|}{ UPLC } \\
\hline & CFC & MP & CFC & MP \\
\hline Linear & & & & \\
\hline Range $(\mu \mathrm{g} / \mathrm{mL})$ & $70-700$ & $10-200$ & $70-700$ & $10-200$ \\
\hline Slope & 2.2033 & 5.434 & 2.1976 & 10.6332 \\
\hline Intercept & 3.6943 & 10.601 & 1.6449 & 4.0712 \\
\hline Correlation coefficient & 0.9998 & 0.9998 & 0.9999 & 0.9999 \\
\hline Repeatability & 0.12 & 0.21 & 0.08 & 0.33 \\
\hline LOD a $(\mu \mathrm{g} / \mathrm{mL})$ & 4.31 & 1.6 & 3.8 & 1.2 \\
\hline LOQ a $(\mu \mathrm{g} / \mathrm{mL})$ & 13.06 & 4.8 & 9.7 & 3.8 \\
\hline
\end{tabular}

\section{Accuracy and Recovery}

Table 4: Data of accuracy and recovery for CFC and MP by the proposed HPLC and UPLC methods.

\begin{tabular}{|c|c|c|c|c|c|}
\hline CFC Standard Solution $(\mu \mathrm{g} / \mathrm{mL})$ & MP Standard Solution $(\mu \mathrm{g} / \mathrm{mL})$ & \multicolumn{2}{|c|}{ HPLC Recovery\% } & \multicolumn{2}{|c|}{ UPLC Recovery\% } \\
\hline \multirow{4}{*}{\multicolumn{2}{|c|}{70}} & CFC & MP & CFC & MP \\
\hline & & 98 & 100 & 98.7 & 99.5 \\
\hline & & 99 & 98 & 98.3 & 99.3 \\
\hline & & 99 & 100.7 & 99.4 & 100.3 \\
\hline \multirow{3}{*}{\multicolumn{2}{|c|}{100}} & 101 & 98 & 99 & 100.2 \\
\hline & & 100 & 99 & 99.4 & 100.4 \\
\hline & & 100.3 & 99 & 99.2 & 100.1 \\
\hline \multirow{3}{*}{\multicolumn{2}{|c|}{170}} & 100.5 & 100.6 & 100.2 & 99.8 \\
\hline & & 99.7 & 100.8 & 100.5 & 99.3 \\
\hline & & 99.8 & 99.8 & 100.33 & 99.8 \\
\hline Accuracy (Mean) \pm RSD & & $99.70 \pm 0.91$ & $99.54 \pm 1.10$ & $99.45 \pm 0.76$ & $99.86 \pm 0.42$ \\
\hline
\end{tabular}

The recovery is calculated for triplicate of three concentrations $(70,100$ and $170 \mu \mathrm{g} / \mathrm{mL})$ comparing the individual peak response with that of the reference solution. As mentioned in (Table 4).

\section{Precision}

Repeatability: repeatability is proceeded using 6 replicates of the standard solution of the compound being studied (625 $\mu \mathrm{g} / \mathrm{mL})$ for $\mathrm{CFC}$ and $(150 \mu \mathrm{g} / \mathrm{mL})$ for MP. The system is precise as the relative standard deviation RSD $\leq 2 \%$. High precision of the method is obtained as shown in (Table 3). Intermediate precision (ruggedness): Intermediate precision expresses the within-laboratories variations: different days, different analysts, different equipment's, etc. Good results are obtained and presented in (Table 5).

Robustness: for measuring the capability of the method to remain unaffected by small, but deliberate, variations in method's parameters such as: influence of variations of flow 
rate change $( \pm 0.1 \mathrm{~mL} / \mathrm{min})$, wave length change $(265 \pm 2.0 \mathrm{~nm})$, column temperature change $\left(25 \pm 5{ }^{\circ} \mathrm{C}\right)$, and $\mathrm{pH}$ of the mobile phase $( \pm 0.2)$. Good results are gained as presented in (Table 5 ).

Stability of the analytical solution: After preparing the standard solution, part of it was stored in fridge and another one is stored at room temperature. After about 24 hours, these solutions are tested against freshly prepared standard; relative standard deviation should be less than $2 \%$. These results are displayed in (Table 5).

\section{Assay of Dosage Form}

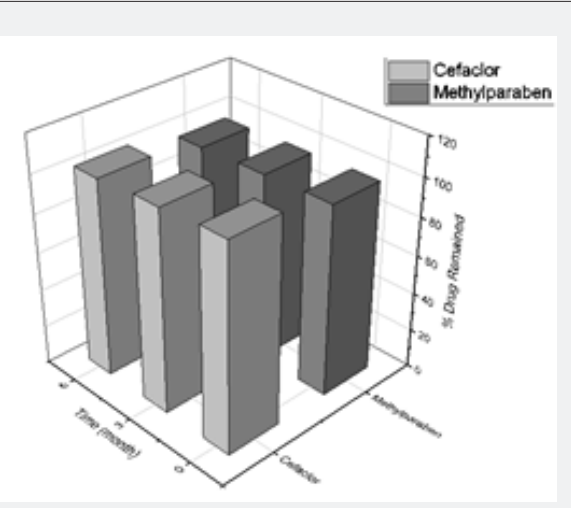

Figure 6: Assay remained (\%) of CFC and MP in Alfatil $125 \mathrm{mg} / 5 \mathrm{~mL}$ "POS stored for six months at $40^{\circ} \mathrm{C} \& 75 \% \mathrm{RH}$.
The suggested method is performed by assaying six samples from the finished product with the same concentration (Alfatil ${ }^{\circledR} 125 \mathrm{mg} / 5 \mathrm{~mL}$ POS) to determine the assay of CFC and MP (Figure 6). The obtained results are displayed in (Table 6).

\section{System Suitability}

System suitability testing is an integral part of much analytical procedure. The tests are based on the concept that the equipment's, electronics, analytical operations and samples to be analyzed constitute an integral system that can be evaluated as such. System suitability is checked by calculating the tailing factor (T), column efficiency $(\mathrm{N})$, resolution (Rs) factors. All calculated parameters are found to be within the acceptable limits indicating good selectivity of the method and assuring system performance (Table 7).

\section{Specificity}

Method selectivity is established for the finished product being studied and placebos matrix containing all excipients of the dosage form. The results referred that no interference is detected at the retention times of CFC and MP in placebo solution. Also, the standard addition technique is applied by adding known concentrations of pure form for both drugs to dosage form and the recovery of the added pure forms are calculated to check the specificity and selectivity of the method. The obtained results are shown in (Table 6).

Table 5: Ruggedness, robustness and stability of analytical solution of the proposed methods.

\begin{tabular}{|c|c|c|c|c|c|}
\hline \multirow{2}{*}{ Parameter } & \multicolumn{2}{|c|}{ HPLC } & \multicolumn{2}{|c|}{ UPLC } & Limit \% \\
\hline & CFC & MP & CFC & MP & \multirow{11}{*}{$\mathrm{RSD} \leq 2.0 \%$} \\
\hline Day to Day & 0.8 & 0.7 & 0.4 & 0.6 & \\
\hline Analyst to Analyst & 0.9 & 1.2 & 0.6 & 0.8 & \\
\hline Column to Column & 0.5 & 0.8 & 0.6 & 0.9 & \\
\hline Flow rate change $( \pm 0.1 \mathrm{~mL} / \mathrm{min})$ & 0.7 & 0.9 & 0.5 & 0.7 & \\
\hline pH changes of mobile phase $( \pm 0.2)$ & 0.8 & 0.9 & 0.9 & 0.8 & \\
\hline Wave length change $(230 \pm 2.0 \mathrm{~nm})$ & 1 & 1.3 & 0.9 & 1 & \\
\hline Column temperature change $\left(30,25{ }^{\circ} \mathrm{C}\right)$ & 1.2 & 1.4 & 1 & 0.8 & \\
\hline Fresh Sample & 0.2 & 0.3 & 0.2 & 0.2 & \\
\hline Stored Sample in fridge & 0.4 & 0.5 & 0.5 & 0.5 & \\
\hline Stored Sample in room temperature & 0.8 & 0.8 & 0.7 & 0.9 & \\
\hline
\end{tabular}

Table 6: Assay results for the determination of CFC and MP in their dosage form by the proposed HPLC and UPLC methods and application of standard addition technique.

\begin{tabular}{|c|c|c|c|c|c|}
\hline $\begin{array}{l}\text { CFC Standard Solution add } \\
\qquad(\mu \mathrm{g} / \mathrm{mL})\end{array}$ & $\begin{array}{l}\text { MP Standard Solution add } \\
\qquad(\mu \mathrm{g} / \mathrm{mL})\end{array}$ & \multicolumn{2}{|c|}{ HPLC Recovery\% } & \multicolumn{2}{|c|}{ UPLC Recovery\% } \\
\hline \multirow{4}{*}{10} & \multirow{4}{*}{10} & $\mathrm{CFC}$ & MP & $\mathrm{CFC}$ & MP \\
\hline & & 99 & 98 & 99.5 & 99.3 \\
\hline & & 98 & 99 & 99.6 & 99.5 \\
\hline & & 98.7 & 99 & 99.3 & 98.6 \\
\hline \multirow{3}{*}{20} & \multirow{3}{*}{20} & 100 & 99 & 98 & 99.8 \\
\hline & & 99 & 98 & 99 & 99.4 \\
\hline & & 100 & 99 & 99.5 & 99.3 \\
\hline
\end{tabular}


Global Journal of Otolaryngology

\begin{tabular}{|c|c|c|c|c|c|}
\hline 30 & 30 & 100 & 98 & 100.3 & 100.3 \\
\hline & & 99.5 & 98 & 100.1 & 100.8 \\
\cline { 2 - 6 } & & 99.1 & 98.6 & 100.7 & 100.1 \\
\hline Accuracy (Mean) \pm RSD & & $99.26 \pm 0.69$ & $98.51 \pm 0.50$ & $99.56 \pm 0.79$ & $99.68 \pm 0.65$ \\
\hline
\end{tabular}

Table 7: System suitability testing parameters of the developed methods.

\begin{tabular}{|c|c|c|c|c|c|}
\hline \multirow{2}{*}{ Item } & \multicolumn{2}{|c|}{ HPLC } & \multicolumn{2}{|c|}{ UPLC } & \multirow{2}{*}{ Reference values } \\
\hline & CFC & MP & CFC & MP & \\
\hline Tailing factor & 1.2 & 1.3 & 0.88 & 0.77 & $\mathrm{~T} \leq 2$ \\
\hline Injection precision & 0.15 & 0.33 & 0.08 & 0.26 & $\mathrm{RSD} \leq 1 \%$ \\
\hline Number of theoretical plates $(\mathrm{N})$ & 3300 & 4125 & 7568 & 5693 & $\mathrm{~N}>2000$ \\
\hline Resolution & - & 4.8 & 5.6 & 6.2 & Rs $>2$ \\
\hline Retention time $\left(\mathrm{R}_{\mathrm{t}}\right)$ & 0.12 & 0.18 & 0.13 & 0.07 & $\mathrm{RSD} \leq 1 \%$ \\
\hline Selectivity & - & 3.2 & 3.7 & 4 & $\mathrm{k}^{\prime}>2$ \\
\hline
\end{tabular}

\section{Drug Remained under Accelerated Condition}

Accelerated stability study intended to increase the rate of physical changes as (appearance, $\mathrm{pH}$, water content...etc.) or chemical degradation (assay, dissolution, related substances and so on) by using immoderate conditions of elevated temperature and humidity. So, stability study is performed under storage conditions $\left(40 \pm 2^{\circ} \mathrm{C} / 75 \pm 5 \% \mathrm{RH}\right.$ (relative humidity) for six months. Products are recommended to analysis at three points (e.g. 0, 3 and 6 months). The obtained results shown in (Table 8).

Table 8: Accelerated stability study results for the determination of CFC and MP in their dosage form by the proposed HPLC method.

\begin{tabular}{|c|c|c|c|c|}
\hline \multirow{3}{*}{$\begin{array}{c}\text { Pharmaceutical } \\
\text { formulation Alfatil } 125 \\
\text { POS }\end{array}$} & \multicolumn{3}{|c|}{ HPLC } & \multirow{3}{*}{ Limit\% } \\
\hline & \multicolumn{3}{|c|}{$\begin{array}{c}\text { Accelerated Stability } \\
\text { Studies }\end{array}$} & \\
\hline & 0 & 3 & 6 & \\
\hline Cefaclor & 107 & 105 & 103 & \multirow{2}{*}{$90-120 \%$} \\
\hline Methylparaben & 99 & 98 & 97 & \\
\hline
\end{tabular}

\section{Conclusion}

A novel, accurate and sensitive RP-HPLC-DAD and RPUPLC methods were validated and developed according to the requirements of ICH guidelines for the simultaneous determination of cefaclor and methylparaben in their dosage form and in its impurity (cefaclor-delta-3-isomer). Based on the above results, the analytical method is valid, achieved reduced time for analysis of assay \& related compound and can be used for regular routine quality control analysis and stability study.

\section{References}

1. Catania S, Gallo A (2004) Clinical efficacy and tolerability of short course therapy with cefaclor compared with long-term therapy for treatment of acute otitis media in children. Infez Med 12(4): 259-265.

2. Aggarwal M, Sinha R, Murali MV, Trihan P, Singhal PK (2005) Comparative efficacy and safety evaluation of cefaclor VS amoxycillin+ calvulanate in children with Acute Otitis Media (AOM). The Indian Journal of Pediatrics 72(3): 233-238.

3. (2017) British Pharmacopoeia.ationary Office; Medicines and Healthcare Products Regulatory Agency; London p. 2.
4. (2006) Description and Clinical Pharmacology for Cefaclor Drug. U. S. Food and Drug Administration.

5. (2018) United States Pharmacopoeia Convention Inc, 41 Revision, NF 36.

6. Zendelovska D, Stafilov T, Petrov S (2002) Simultaneous quantification of cefaclor and cephalexin in blood plasma using high-performance liquid chromatography with UV detection. Acta Pharmaceutica 52(4): 243-250.

7. Medenecka B, Jelińska A, Zajac M, Bałdyka M, Juszkiewicz K, et al. (2009) Stability of the crystalline form of cefaclor monohydrate and its pharmaceutical preparations. Acta poloniae pharmaceutica 66(5): 563-569.

8. Rao MVB, Prasanthi V, Sushanta M, Raja G (2011) Development and Validation of New RP-HPLC Method for the Determination of Cefaclor in Pharmaceutical Dosage forms and in Human Plasma. Research Journal of Chemical Sciences 1(5): 36-39.

9. Tarawneh KA, Halasah ZA, Khleifat AM, Batarseh MI, Khleifat KM, et al. (2011) Evaluation of cefaclor oral suspensions stability using reversed phase high performance liquid chromatography and antimicrobial diffusion methods. Pakistan journal of pharmaceutical sciences 24(3): 303-313.

10. Dayyih WAA, Mallah EM, Al-Akayleh FT, Hamad MF, Arafat TA (2013) A stability-indicating high-performance liquid chromatographic (HPLC) assay for the determination of cefaclor in biological fluid. Latin American Journal of Pharmacy 32(4): 568-574.

11. Shah J, Rasul Jan M, Shah S, Naeem Khan M (2013) Development and validation of HPLC method for simultaneous determination of ceftriaxone and cefaclor in commercial formulations and biological samples. Journal of the Mexican Chemical Society 57(4): 314-320.

12. Sivanadh MV, Prasanthi K, Subhashini MV, Rao B (2016) New Validated RP-HPLC Method for the Estimation of Cefaclor in Pharmaceutical Formulation. Scholars Research Library 8: 318-324.

13. Abdollahpour A, Forouhi M, Shamsipur M, Yamini Y (2010) High performance liquid chromatographic determination of sodium benzoate, methylparaben and propylparaben as preservative components in nystatin suspensions. Journal of the Iranian Chemical Society, 7(2): 516520 .

14. Shabir GA (2010) A new validated HPLC method for the simultaneous determination of 2-phenoxyethanol, methylparaben, ethylparaben and propylparaben in a pharmaceutical gel. Indian journal of pharmaceutical sciences 72(4): 421-425.

15. El-Gindy A, Attia KAS, Nassar MW, Abu Seada HH, Shoeib MAS (2013) HPLC method for determination of paracetamol, psedoephedrine, 
triprolidine, methylparaben, propylparaben, sodium benzoate, and their related substances in pharmaceutical syrup. Journal of Liquid Chromatography \& Related Technologies 36(9): 1251-1263.

16. Antakli S, Kabani R, Shawa D (2013) Determination of Preservative Parabens in Oral and Injection Formulations by HPLC. Asian Journal of Chemistry 25(2): 1123-1128.

17. Solangi AR, Memon SQ Khuhawar MY, Bhanger MI (2007) Quantitative analysis of eight cephalosporin antibiotics in pharmaceutical products and urine by capillary zone electrophoresis. Acta Chromatographica 19: 81-96.

18. Hancu G, Kelemen H, Rusu A, Gyéresi Á (2013) Development of a capillary electrophoresis method for the simultaneous determination of cephalosporins. Journal of the Serbian Chemical Society 78(9): 14131423.

19. Sako AV, Dolzan MD, Micke GA (2015) Fast and sensitive method to determine parabens by capillary electrophoresis using automatic reverse electrode polarity stacking mode: application to hair samples. Analytical and bioanalytical chemistry 407(24): 7333-7339.

20. Agbaba D, Eric S, Zivanov Stakic D, Vladimirov S (1998) HPTLC assay of cephalexin and cefaclor in pharmaceuticals. Biomedical Chromatography 12(3): 133-135.

21. Dąbrowska M, Krzek J (2010) Separation, identification, and quantitative analysis of the epimers of cefaclor by TLC-densitometry. JPC-Journal of Planar Chromatography-Modern TLC 23(4): 265-269.

22. Gupta A, Dassani J (2013) TLC Separation of Cephalosporins on Stannic Arsenate Layers. IOSR-JAC 4: 05-10.

23. Huang C, Wang W, Miao L (2013) Determination of Cefaclor by UPLCMS-MS for a Chinese Pharmacokinetic Study. Journal of chromatographic science 52(7): 636-640.

24. YU S, Lee B, Lee M, Cho I, Chang SW (2008) Decomposition and mineralization of Cefaclor by ionizing radiation: Kinetics and effects of the radical scavengers. Chemosphere 71(11): 2106-2112.

25. Nagori BP, Shukla SS (2008) New spectrophotometric determination of cefaclor in bulk drug and synthetic mixture. Asian Journal of research in chemistry 1(1): 51-52.
26. Raza A, Ijaz AS, Ahmad S (2009) Development and application of spectrophotometric method for the determination of cefaclor in pharmaceutical formulations. Química Nova 32(5): 1180-1183.

27. Mohammad AA (2016) Comparison of HPLC and UV Spectrophotometric Methods for the Determination of Cefaclor Monohydrate in Pharmaceutical Dosages. Med. Chem 6: 019-022.

28. Esteki M, Nouroozi S, Shahsavari Z (2016) A fast and direct spectrophotometric method for the simultaneous determination of methyl paraben and hydroquinone in cosmetic products using successive projections algorithm. International journal of cosmetic science 38(1): 25-34.

29. Ahmed A MK, Khazaal AS, Ahmed AH (2018) Spectrophotometric Determination of Methyl Paraben in Pharmaceutical Formulations by Oxidative Coupling Reaction. Tikrit Journal of Pure Science 21(6): 85-89.

30. Yahyaa SY (2017) Spectrophotometric method for the microdetermination of methyl and propyl paraben in some detergents through charge transfer complex. Iraqi National Journal of Chemistry 17(1): 87-102.

31. Mangesh PP, Baliram WS, Digambar CP (2013) Simultaneous determination of ketopfofen and methyl paraben, propyl paraben in bulk and formulated gel by spectrophotometry. J. Pharm. Sci. Innov 2: 22-28.

32. Chilukala S, Bontha VK, Pragada RR (2016) In Vitro And In Vivo Characterization of Cefaclor Loaded Floating Microspheres. Indo American Journal of Pharmaceutical Research 6: 5277-5281.

33. Alexandru BDGT, Simona MD, Corneliu B, MARIA B, Adriana MM, Elena PD, ȘTEFAN RF (2012) Comparative in-vitro study of immediate and modified released oral dosage forms of cefaclor. Farmacia 60(3): 334341.

34. Mahmoud AM, Amr HA, Abdelfatah MA, Mahmoud OA (2018) Validation and Comparative In-vitro Dissolution Studies of Cefaclor in Their Powder for Oral Suspension Dosage Forms, Analytical Chemistry Letters 8(1): 88-103.

35. (2005) ICH Guidelines. Q2 (R1): Validation of Analytical Procedures: Text and Methodology, International Conference on Harmonization IFPMA, Geneva, Switzerland.

\begin{tabular}{l} 
Your next submission with Juniper Publishers \\
will reach you the below assets \\
- Quality Editorial service \\
- Swift Peer Review \\
- Reprints availability \\
- E-prints Service \\
- Manuscript Podcast for convenient understanding \\
- Global attainment for your research \\
- Manuscript accessibility in different formats \\
( Pdf, E-pub, Full Text, Audio) \\
- Unceasing customer service \\
Track the below URL for one-step submission \\
https://juniperpublishers.com/online-submission.php \\
\hline
\end{tabular}

